\title{
A COMPARISON BETWEEN THE USE OF CISCO PACKET TRACER AND GRAPHICAL NETWORK SIMULATOR 3 AS LEARNING MEDIA ON STUDENTS' ACHIEVEMENT
}

\author{
Liska Mey Ika Sari ${ }^{1}$, Puspanda Hatta $^{2}$, Endar S Wihidayat $^{3}$, FENG Xiao ${ }^{4}$ \\ 1,2,3 Study Program of Informatics and Computer Engineering Education, Sebelas Maret University, Indonesia \\ ${ }^{4}$ Sino-German Institute of Vocational Education, Tongji University, Shanghai, China \\ E-mail: meitha.liska@gmail.com
}

\begin{abstract}
Usually in studying the practice of computer networks, it is encountered several obstacles such as (1) limited computer networks design tools, (2) limited learning time to design computer networks and (3) technical difficulties for finding the solutions of errors. To overcome those barriers as proposed in this study, computer network simulators were used. Computer network simulators were expected to help students designing and simulating networks planned to be applied to computer network practices. This study used two simulators to compare its effectiveness in assisting the students to learn computer networks, which were Cisco Packet Tracer and Graphical Network Simulator 3 (GNS3). This study was aimed to determine the difference of the influence of network simulators to (1) learning achievement, and (2) learning achievement improvement. The quasiexperiment method was used and data were collected through conducting testing before and after the utilization of the simulators. Based on the testing results it was concluded that (1) different effect of using Cisco Packet Tracer and GNS3, the average grade achievement in the class using GNS3 and using Cisco packet tracer were 76.67 and 70 respectively, and (2) improved learning achievement using GNS3 for around 35\%, higher than using Cisco Packet Tracer.
\end{abstract}

Keywords: cisco packet tracer, gns3, learning achievement, networking simulator

\section{INTRODUCTION}

The success of a learning process at school is influenced by internal factors and external factors. Internal factor involves student's skills such as motoric skills and thinking schemes. External factors include teachers, school environment, school curriculum, instructional media, and school infrastructure (Aunurrahman, 2014). Learning media can be defined as a medium that carries messages or information aimed at instructional or contains learning purposes, which are used to convey the content of teaching materials (Arsyad, 2011). The instructional media include books, audio, video, slides, photos, pictures, graphics, simulators, and others (Anitah, 2008). Learning Media is an essential aspect of a learning process that significantly influences the learning outcomes (Tiwan, 2012; Suyitno, 2016; Marsudi, 2016).

Many Vocational High Schools, also known as Sekolah Menengah Kejuruan (SMK), open Computer Networking Engineering Programs or Teknik Komputer dan Jaringan (TKJ). In this program, the students would learn design of computer networks, create a computer network and network server administration. During the program, it is found many problems such as (1) the lack of network devices (2) takes a long time in the networking process (3) difficulties to find solutions when facing constraints or errors (Hariyanto \& Nugraha, 2012).

A possible way to reduce the failure rate of network practices is using a simulator to help learning computer networks. Network simulators are expected to help students designing and simulating networks that will be applied to the actual networks afterwards. The network simulator that has been widely used in the learning process is Cisco Packet Tracer. Javid (2014) found that the benefit of Cisco Packet Tracer is the students can learn basic concepts of computer networks and they also can simulate a computer network without 
buying expensive tools. Comparing to the previous simulator, this study proposes GNS3 as a new simulator to be tested (Maizura et al., 2018). Cisco Packet Tracer and GNS3 have some similarities such as free software and they can be run on operating systems such as windows and Linux. However by using GNS3, it is possible to run Cisco IOS (Internet Operating System) and make it a more real topology with interaction to other systems like OS that exist in VirtualBox.

The study is supported by Vesel et al. (2016) who discussed the media that can be used for modeling network structure. They claimed that GNS3 was a good network software used for simulation of computer networks that approached the creation of a real network, so GNS3 become the right software for computer network modeling.

In addition, Handayani et al. (2012) discussed the making network design using Multiprotocol Label Switching (MPLS) technology and simulation using Graphical Network Simulator (GNS3) which connect several campus locations to improve network performance. GNS3 is a network simulator that can be used to simulate a complex MPLS network well. This simulator is useful for network technicians to check the configuration that needs to be used before being implemented to the real router.

Twelefty \& Zani (2015) developed an application of clustering computing system which would be applied in computer network laboratories by using a GNS3 simulator. The simulator was used as a laboratory testing tool to implement the GNS3 cluster system on network simulations and simulate the core network of a building. The results indicated that the cluster system can be implemented using GNS3.

This study is an effort to improve the students' learning achievement by using simulator-based learning media. The network learning theoretical materials to be delivered can be simulated before the real equipment practices. The purpose of this study is to examine the impact of network simulator usage (1) learning performance and (2) learning achievement.

\section{METHOD}

This section discusses the research methods which is consists of the research the research design, the research sample and data collection techniques. Using quasi-experiment design, there are two groupes compared, the control group treated with Cisco Packet Tracer, and the experimental group treated with GNS3. Both groups will get pre-test and post-test before and after the treatment. For the detailed design of this study adapted from Sugiyono (2010), it is presented in Table 1.

Table 1. Research Design

\begin{tabular}{llll}
\hline Group & Pretest & Treatment & Posttest \\
\hline Experiment & $\mathrm{O}_{1}$ & $\mathrm{X}_{1}$ & $\mathrm{O}_{2}$ \\
Control & $\mathrm{O}_{3}$ & $\mathrm{X}_{2}$ & $\mathrm{O}_{4}$ \\
\hline Where & & \\
$\mathrm{O}_{1}$ : Pretest Experimental Group \\
$\mathrm{O}_{2}$ : Posttest Experimental Group \\
$\mathrm{O}_{3}$ : Pretest Control Group \\
$\mathrm{O}_{4}$ : Posttest Control Group \\
$\mathrm{X}_{1}$ : Use of GNS3 Simulator Learning Media \\
$\mathrm{X}_{2}$ : Use of Cisco Packet Tracer Simulator \\
Learning Media
\end{tabular}

Based on Table 1, there were two groups to apply the design and then they were assessed using a pretest to know the students' prior abilities. The results will consider as proper or valid if the two groups' prior abilities do not differ significantly. Then both groups were treated, X1 was treated using a GNS3 simulator and X2 treated with a Cisco Packet Tracer. After being treated, both groups performed a post-test. This study used total sampling technique which means the number of samples is equal to the number of population (Arikunto, 2006). 72 students of SMK N 1 Sukoharjo had participated in the study divided into 2 for the experimental group and the control group. For collecting the data, it was conducted a test. A 
test is a collection of questions or exercises used to measure the students' skills, knowledge of intelligence, and abilities or talents possessed by individuals or groups (Arikunto, 2006). The test was aimed to assess the difference in learning achievement of each group.

The data analysis was done by conducting a balance test, a normality test, a homogeneity test and a hypothesis test. All tests were performed before hypothesis testing. The equilibrium test result was measured by the pretest value through a t-test. The result of the balance is 0.278 , a lot greater than 0.05 , which meant that the sample has the same initial ability.

The results of the normality test obtained the pre-test results of the control group and experiment group were 0.123 and 0.285 respectively. While the post-test results of the control group and experiment group were 0.131 and 0.606 respectively. Thus, the result of the normality test as a whole was more than 0.05 . It is shown that the results of the normality test from the pretest and posttest of the experimental group and the control group were normally distributed. From the homogen test results of the control and experiment group, it was obtained sig value at the pretest and posttest which were 0.565 and 0.172 respectively. Because both of the sig values were more than 0.05 then it was concluded that the data were homogenous. Based on the results of data analysis, the data in this study was normally distributed and homogeneous, and so it could be continued with a hypothesis and a parametic statistic test.

\section{RESULTS AND DISCUSSION}

The hypothesis testing was conducted after the Cisco Packet Tracer and GNS 3 were implanted on the subject of the study, then data collection and analysis were conducted. The results of data collection and analysis showed that the result has been fulfilled, equal to the pretest, homogenous and normal, then it was tested using the independent test sample hypothesis test. The Result of Hypothesis testing was presented in Table 2 .

Tabel 2.The Result of Hypothesis Testing

\begin{tabular}{llllll}
\hline Group & $\mathrm{N}$ & Sig & $\begin{array}{l}\alpha= \\
5 \%\end{array}$ & Criteria & Information \\
\hline $\begin{array}{l}\text { Experiment } \\
\text { \& control }\end{array}$ & 36 & 0.000 & 0.05 & $\begin{array}{l}0.000< \\
0.05\end{array}$ & H0 rejected \\
H1 accepted
\end{tabular}

Table 2 shows the result of Hypothesis Testing with sigficance less than 0.05 and $t_{\text {count }}$

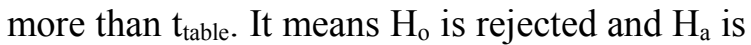
accepted. Therefore there is a significant difference before and after the implementation of the media in each group. There was increasing average in the experiment group values which was higher than the control group. In the control group the increase was around 4.03 while the experimental group was 12.64. In summary, the results of this test accepted the hypothesis of different impact of the use of Cisco Packet Tracer and GNS3 simulator as a medium of learning on student achievement in the subject of LAN network installation. There is different impact on students' achievement improvement between the learning process by using Cisco Packet Tracer and by using GNS3 simulators on the LAN Network Installation subject indicated by the post-test results.The post-test results of the experimental and control groups are presented in Table 3 and Figure 1.

Tabel 3. Posttest Result of the Control Group and the Experimental Group

\begin{tabular}{cccc}
\hline Group & Min Value & Max value & Average Value \\
\hline Control & 55 & 80 & 70 \\
Experimental & 60 & 95 & 76.67 \\
\hline
\end{tabular}




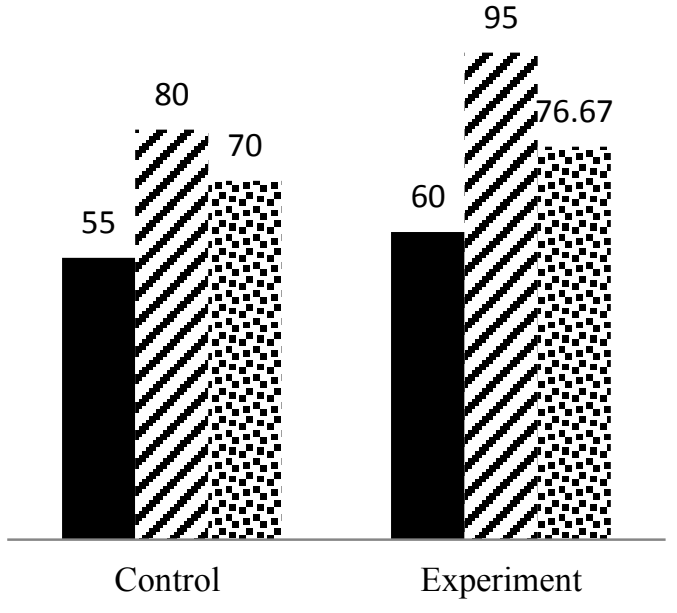

Figure 1 Posttest Results of the Control Group and the Experimental Group

Table 4. Gain Index

\begin{tabular}{cccccc}
\hline Group & Pretest & Posttest & Gain & $\begin{array}{c}\text { Standart } \\
\text { Gain }\end{array}$ & Classification \\
\hline Experiment & 64.02 & 76.66 & 12.64 & 0.35 & Medium \\
Control & 65.67 & 70 & 4.33 & 0.11 & Low \\
\hline
\end{tabular}

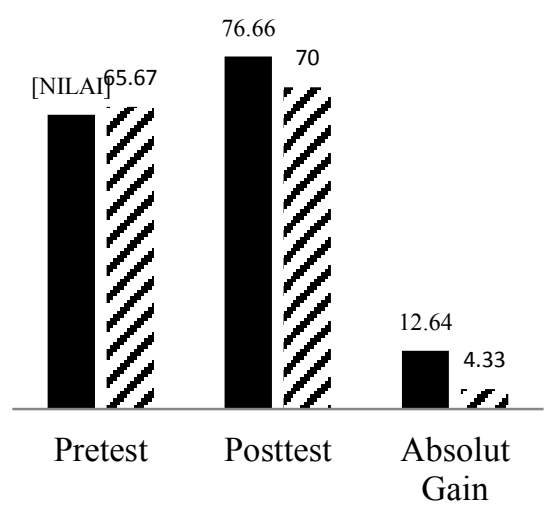

- Experiment Group ¿ Control Group

Figure 2. The Score of Control Group Experiment

Table 4 and Figure 2 show the results of the experimental group gain. The calculation of the experiments increased by 0.35 categorized as moderate and in the control group it was increased by 0.11 categorized as low. From the results of the gain index, it can be concluded that students learning achievement in the experimental group is higher than the control group.
Table 3 and Figure 1 present the minimum values of the control group and the experimental group are 55 and 60 respectively. While the maximum value of the control group and the experimental group are 80 and 95 respectively. The mean scores of the two groups are also different. The mean scores for the control group and the experimental group are 70 and 76.67 respectively. The experimental group got the higher result than the control group. The result is supported by the improvement of student achievement using a gain index test presented in Table 4. 
is different impact on learning achievement between students treated with Cisco Packet Tracer and GNS3. The students' learning achievement treated with GNS3 is $35 \%$ which is higher than the students treated with Cisco Packet Tracer students with the percentage of $11 \%$.

\section{REFERENCES}

Anitah, S. 2008. Media Pembelajaran (2 $2^{\text {nd }}$ ed.). Lembaga Pengembangan Pendidikan (LPP) UNS dan UPT Penertiban dan Percetakan UNS (UNS Press)

Arikunto, S. 2006. Prosedur Penelitian Suatu Pendekatan Praktik (13 ${ }^{\text {th }}$ ed.). Jakarta: PT Rineka Cipta

Arsyad, A. 2011. Media Pembelajaran. Jakarta: Rajawali Pers.

Aunurrahman. 2014. Belajar dan Pembelajaran. Bandung: CV Alfabeta

Handayani, N. K., Rochim, A. F., \& Isnanto, R. R. (n.d.). Simulasi Jaringan Multiprotocol Label Switching (MPLS) Menggunakan Graphical Network Simulator (GNS3),1-7

Hariyanto, D. \& Nugraha, A. D. H. 2012. Pelatihan Penggunaan Software Simulasi Jaringan "Packet Tracer" untuk Meningkatkan Kompetensi Jaringan di Kabupaten Kulonprogo

Javid, S. R. 2014. Role of Packet Tracer in learning Computer Networks. International Journal of Advanced Research in Computer and Communication Engineering. 3.5, 65086511
Maizura, N., Noor, M., Yayao, N., \& Sulaiman, S. 2018. Effectiveness of Using Cisco Packet Tracer as a Learning Tool: A Case Study of Routing Protocol. 8.1

Marsudi. 2016. Penerapan Model Konstruktivistik dengan Media File Gambar 3D untuk Meningkatkan Motivasi dan Prestasi Hasil Belajar. Jurnal Pendidikan Teknologi dan Kejuruan. 23.1, 16-27

Saputro, J. 2010. Praktikum CCNA Dikomputer Sendiri Menggunakan GNS3 ( $1^{\text {st }}$ ed.). Jakarta: PT Transmedia

Sugiyono. 2010. Metodologi Penelitian Pendidikan (11 ${ }^{\text {th }}$ ed.). Bandung: Alfabeta

Suyitno. 2016. Pengembangan Multimedia Interaktif Pengukuran Teknik untuk Meningkatkan Hasil Belajar Siswa SMK. Jurnal Pendidikan Teknologi dan Kejuruan. 23.1, 101-109

Tiwan. 2012. Peningkatan Prestasi Belajar Mahasiswa pada Mata Komputer Pemrograman melalui Pemanfaatan Recording Macro. Jurnal Pendidikan Teknologi dan Kejuruan.21.1, 90-96

Vesel, P., Karovi, V., \& Karovi, V. 2016. Tools for Modeling Exemplary Network Infrastructures. 98 (Euspn), 174-181.

Y. Twelefty, T. \& Zani, M. F. 2015. Implementasi GNS3 CLUSTER sebagai Alat Bantu Simulasi Jaringan Komputer. 1. 3, 2377-2383 